\title{
FATHOM
}

\section{"He had tied a bit of white worsted round his neck": Focusing on Details in Heart of Darkness}

"Il s'était attaché un bout de fil blanc autour du cou »: le souci du détail dans Cœur des ténèbres

\section{Nathalie Martinière}

\section{OpenEdition}

\section{Journals}

\section{Electronic version}

URL: http://journals.openedition.org/fathom/1062

DOI: $10.4000 /$ fathom.1062

ISSN: 2270-6798

Publisher

Association française sur les études sur Thomas Hardy

\section{Electronic reference}

Nathalie Martinière, " "He had tied a bit of white worsted round his neck": Focusing on Details in Heart of Darkness », FATHOM [Online], 6 | 2019, Online since 01 October 2019, connection on 14 October 2019. URL : http://journals.openedition.org/fathom/1062 ; DOI : 10.4000/fathom.1062 


\title{
"He had tied a bit of white worsted round his neck": Focusing on Details in Heart of Darkness
}

\author{
"Il s'était attaché un bout de fil blanc autour du cou »: le souci du détail dans
}

Cœur des ténèbres

Nathalie Martinière

1 In the preface of The Nigger of Narcissus, Conrad states that, as a writer, his "[task] is, before all, to make you see. That - and no more, and it is everything." What he wants to make us see, if we trust the preface, has to do with "the truth, manifold and one, underlying [...] every aspect [of the visible universe]" (Conrad 1984, xlii). But the truth, in order to be made visible, must be lodged in tangible things: in facts, in characters, in objects.

Conrad was not Dickens or Flaubert, though he knew them very well, and long descriptions of innumerable objects do not abound in his fiction. Many of the objects which do find their place in his stories however mark out significant moments, so much so that they have become emblematic and their meaning has been the source of controversies, interpretations and re-interpretations. The young captain's hat in "The Secret Sharer" is one such example, as is the jubilee sixpence in "Karain" or Brierly's gold chronometer in Lord Jim. Such objects stick out, as if they could be detached from the continuum of the narrative in order to become meaningful and often powerful images in the readers' minds. Others on the contrary seem to be present only to contribute to a "reality effect", ${ }^{1}$ since they cannot be interpreted allegorically and/or do not have a function in the plot: they look like unimportant details. Such are the sorts of objects I would like to deal with in this paper, focusing on Heart of Darkness.

Because "material interests" are so important in Conrad's fiction, I want to concentrate on the material dimension of objects, in order to see "why and how [the author] use[s] objects to make meaning [...]" (Brown 4): apparently unimportant details create circuits of meaning, shedding light not only on the characters they are associated with or 
belong to, but more generally on how colonialism works and what it implies, as is the case with objects made in ivory. I will then focus on one particular case, the white worsted in the "grove of death" scene, ${ }^{2}$ a detail that arrests Marlow's gaze and throws light on Conrad's aesthetic strategy in Heart of Darkness when dealing with what Marlow calls the "unspeakable", "wrapping up the idea in secondary notions" (Conrad 1986, $157)^{3}$ as he put it in one letter, but also helping readers find out "the meaning of [the] episode" (Conrad 2006, 5).

\section{Watching Details}

If one concentrates on the objects at the beginning of Heart of Darkness, apart from the mention of sails, canvas and other elements which constitute the ship's tackle, we notice that there are very few of them: an "only cushion" and an "only rug" on which the lawyer sits, "a box of dominoes" (Conrad 2006, 3), and that is about all. At the end of the story, when Marlow visits the Intended, the description of her drawing-room is slightly more detailed, with "the bent gilt legs and backs of the furniture [...] the tall marble fireplace [...] a grand piano [...] with dark gleams on the flat surfaces like a somber and polished sarcophagus" (73). The narrators are different, but in both cases, their descriptions concentrate on just a few objects which are apparently mentioned in order to characterize the characters' social background. As a consequence, these objects are seen but not used in the fiction: as the frame narrator notices, "we did not begin that game of dominoes" (4); and at the Intended's, no fire is lit in the fireplace, no one plays the piano. Similarly, later in the story, a majority of objects mentioned by Marlow cannot be used, either because, like the "boiler wallowing in the grass" or the "railway-truck lying [...] on its back with its wheels in the air" (15), they are wrecked and no longer of use, or because like Towson's manual, they are written, if not "in cipher" at least in a language Marlow cannot understand, or even because they are repeatedly evoked, hoped for, promised [...] but remain absent, like the rivets. ${ }^{4}$ If such objects are mentioned, it is not because of their use value, or because they are instrumental in the progression of events: nothing that happens in the story happens because of them. It seems that their only function is to be seen and mentioned by the narrators, and particularly by Marlow, their uselessness being a way for him of characterizing the situation in Africa.

5 At first sight, they may appear as insignificant objects arresting the gaze in moments of inactivity (in the case of the frame narrator) or of uneasiness, distress, psychological tension (in the case of Marlow). It must be noticed that, apart from the very first scene, throughout the novella objects are mentioned because they have been perceived by Marlow and have left their mark on his retina and in his mind, as if he were looking for something in objects which is not their use. Hence a number of scenes in which their presence seems meant to create an atmosphere-most of the time a gloomy, gothic atmosphere, as is the case for instance with Kurtz's "small sketch in oils" which strikes Marlow so much because it looks so "sinister" (Conrad 2006, 25).

6 Details, art critic Daniel Arasse tells us, are meant to be "revealing." Surprising us, they strike our gaze because they look either superfluous or they distract us from the general meaning of the work. Details convey "information which is different from the overall message of the work". ${ }^{5}$ Thanks to them, the "work's content or intention is either veiled or unveiled" (Arasse 10). They stop our gaze and disrupt the logic of 
interpretation, opening new paths, ${ }^{6}$ favouring unexpected associations (23) and suggesting new modes of approach: details may seem unimportant or trivial, but they can also be read as "signs" that beckon to us, indicating that there may be other ways of reading a painting, for example. Arasse deals with the visual arts, but his remarks may also apply to literature and particularly Heart of Darkness.

In the novella, Marlow's interest in apparently insignificant objects creates moments of stasis during which his gaze is arrested by their presence, a presence which reverberates on the overall picture. Such is the case for instance with the accountant met by Marlow in the outer Station with his "high starched collar, white cuffs, a light alpaca jacket, snowy trousers, a clear necktie, and varnished boots. No hat. [...] a greenlined parasol held in a big white hand." Marlow is clearly fascinated by the man and his attire: he calls him a "miracle" and compares him to a "vision", saying that he " respected his collars, his vast cuffs [...]" (Conrad 2006, 18) - not that he respected the man. The accountant's clothes obviously stand for European-ness and European "civilization". Adding that "his starched collars and got-up shirt-fronts were achievements of character" and that he had "backbone", Marlow encourages a psychological interpretation, the accountant becoming a model of resistance to the "destructive" influence of the African climate, "[keeping] up his appearance in the great demoralization of the land" (emphasis mine). In a novella that deals explicitly with the effect of "the powers of darkness" on Europeans, such a reading of the role of the accountant's clothes seems only legitimate. But, if it looks like the most obvious interpretation, it is not the only one, as Marlow immediately adds that the man "[had] been teaching one of the native women about the station [to clean and starch his linen]. It was difficult. She had a distaste for the work" (18). As has been underlined by critics already, what this understatement reveals is that the mention of the accountant's clothes may have another function in the story. The white cuffs and starched shirt can be read as a form of comment on the presence of such a glaringly "white" character in Africa: such details are not only an idiosyncrasy, a proof of the accountant's eccentricity and attachment to European "manners", they also point at the subjection of the woman. Marlow concludes that "this man had verily accomplished something" (18, emphasis mine). It remains for the readers to understand that he has pushed the logic of exploitation to a degree where the detail reveals a whole system of relationships between Europeans and natives, based on coercion.

8 Thus objects are two-faced: considered in relation with characters, they can be interpreted as revealers of their psychology and serve as elements of characterization or contribute to the creation of an atmosphere, in true Victorian fashion. But there is another way of seeing them, which has to do with where they come from, how they were obtained, why they are where they are, what amount of work or servicing they need, etc., in other words with their history as objects outside the text. In The Ideas in Things, Elaine Freedgood insists on the fact that "objects in texts may have connections beyond the covers of the text, or outside the frame of the narrative" (Freedgood 11), pointing out that things that tend to be considered as pertaining only to the reality effect should be considered for themselves, "in terms of their own properties and history", as they may enable us to perceive "the play of history" "haunting" the text, although generally overlooked. ${ }^{7}$ Objects may look like details, but their own story throws a different light on the general picture: seen as elements in a system of relationships, they point to the material realities dealt with in Heart of Darkness. Therefore, they shed light on the economic and cultural implications of the story told 
by Marlow. From that point of view, objects in the novella have a lot to tell us about colonialism, and more particularly that economy and culture cannot be dissociated. In fact, it is in the presence of objects, in their description and in the way they are characterized, as much as in the relationships between characters, that the reality of colonialism is made clear:

'Everything else in the station was in a muddle - heads, things, buildings. Strings of dusty niggers with splay feet arrived and departed; a stream of manufactured goods, rubbishy cottons, beads, and brass-wire set into the depths of darkness, and in return came $a$ precious trickle of ivory. (Conrad 2006, 18; emphasis mine)

Saying this, Marlow points out that the presence of objects there is the result of exchanges: the station is filled with "manufactured goods" coming from Europe, which he characterizes as "rubbishy", 8 to be exchanged for "precious [...] ivory" (Conrad 2006, 18). The imbalance in this system of circulation and exchange is double as is underlined by the choice of adjectives and of a water metaphor that contrasts the abundance of valueless trade goods from Europe with the scarceness of what is really valuable and valued, i.e. ivory. Objects therefore become symptoms of the reality of the colonial situation and work as material contradiction to the "civilizing work" (90) extolled by Marlow's aunt (12): if the Europeans bring quantities of objects to Africa and get little out of it, profit is nevertheless on their side, and there is no chance of "civilizing" the natives with glass beads and brass-wire.

\section{The Many Lives of Ivory}

10 As we can see, the presence of objects which may look like mere details in the story told by Marlow - defined as the story of a quest for a man -, actually writes a subtext in the novella, which on second reading proves essential to its understanding. Postcolonial criticism, turning its back on psychological or metaphysical interpretations of Heart of Darkness, contributed to the revaluation of such details. An emblematic example is ivory. Of course, ivory is not presented as a detail in the novella, it is the very thing around which everything and everyone in the story revolves. But Conrad did not expect his readers to associate it only with Africa. He also made use of apparently insignificant details in order to saturate his text with its implicit presence, and force readers to acknowledge that they were not distant, outside spectators of what was taking place on a far-away continent.

11 The word "ivory" recurs only 31 times in the story. ${ }^{9}$ Yet its presence can be felt throughout the text if one pays attention to details, marking out important scenes, creating a network of signification and links that "make of that story something quite on another plane than an anecdote of a man who went mad in the centre of Africa" as Conrad put it in one of his letters (Conrad 1986, 417). Throughout Marlow's stay in Africa and his quest for Kurtz, "the word ivory would ring in the air" (Conrad 2006, 35), and it is quite significant that, as the narrator tells us in "An Outpost of Progress", "the storehouse [for ivory] was called the fetish" (Conrad 1983, 89), a term that underlines the layer of values ivory is endowed with: an image of power invested with an erotic dimension (Kurtz's African mistress is covered with "the value of several elephant tusks"; Conrad 2006, 60), ivory is also the object of what Marx called "commodity fetishism". For Marx, commodity fetishism conceals the relationships between people (or with animals) involved in the production of goods (workers and capitalist) behind 
the economic exchange of money and commodities: "It is nothing but the definite social relation between men themselves which assumes here, for them, the fantastic form of a relation between things" (Marx 165). In "An Outpost of Progress", when Makola exchanges tusks for the station men, he trespasses on what is acceptable by the white men because he replaces the usual trade goods which can be seen as an equivalent of money (beads and calico), and which seem to confine transactions to the exchange of objects, with human beings. He therefore reveals the true nature of the relationship between colonized and colonizer: it is not an exchange of material goods but slavery. As Elaine Freedgood puts it, "social relations hide in things" (Freedgood 54). And they can be read in things. In Heart of Darkness, the same idea is conveyed in a much less direct or explicit manner, when Marlow speaks of the "strings" of black workers, thus making a parallel with the (strings of) beads that serve for payment of the ivory - his way of underlining that the natives are turned into objects themselves. But the situation is made more complex because Marlow's narrative is framed by scenes that take place not in Africa, where ivory is to be had, but in Europe, on the Thames and in Brussels. There, the precious raw material is never mentioned, at least never directly. Yet, as has been underlined, ivory is nevertheless present. It is present under a form that leaves the raw material out, in background details that seem largely disconnected from the main story: dominoes and piano-keys. First, these objects are never presented as the result of the transformation of ivory into something of a supposedly different nature (but is it?), i.e. utilitarian artefacts valued by the European upper middle classes who never set foot in Africa but who were probably not entirely ignorant of the "geographical and human origins" (Freedgood 8) of these objects (contrary to many later-days readers), if one thinks only of the campaigns against the Congo Free State that took place more or less at the time when the novella was published. Freedgood insists that the Victorians and Edwardians were largely conscious of the power relations hidden in things that seem innocuous enough to us, like mahogany furniture (or in our case piano-keys):

[a]n apparently innocent object like a mahogany dresser or a walnut panel decorates the moral and moralized space of the novel's winners, while sneaking in the true extent of their morally precarious triumph and evoking useful and selfprotective memories of imperial mastery. [...]

Because we, contemporary readers of Victorian fiction, have lost many of the possible meanings of the things of those [...] novels, what might be called the social destruction of meaning in the novel has unwittingly been abetted by practices of reading that ignore the literal or material qualities of objects, the very qualities that might take us back in time to the meanings and resonances these objects may have had for earlier readers. ${ }^{10}$ (Freedgood 51-52)

So piano-keys at the Intended's and dominoes on board the Nellie could look like details to mid- $20^{\text {th }}$ century readers who read Heart of Darkness as a voyage into the self or a metaphysical quest (Hochschild 143). But the meaning of such details was much clearer for the late Victorian or Edwardian readers: their presence had to be re-inserted into the circuit of "exchange", i.e. appropriation, transformation and distribution that guaranteed their availability on the European market. From that point of view, they were no longer details but the logical outcome of the ivory hunt in Africa, giving the attentive reader the key with which to understand why those who went out there behaved as they did. ${ }^{11}$ At the beginning of the novella, Marlow says that what redeems "[t]he conquest of the earth" is "the idea only" (Conrad 2006, 7, emphasis mine), but objects like the dominoes or piano-keys keep pointing at the material reality 
inseparable from the "idea". The "horror" of colonialism may be only a rumour for the European readers, but the mention of such details functions like the return of the repressed and ensures that it remains grounded in reality.

As a consequence, the presence of such details is perfectly necessary and logical. What they tell us is that the frame narrative is not only a frame but the place where everything starts and ends, not a place from which the crimes of colonialism can be judged but their cause. What they reveal is that there is no solution of continuity between Europe and Africa, as the comparison of the piano with a "sarcophagus" (Conrad 2006, 173) suggests: the victims of colonialization may be buried in Africa, but their ghosts have travelled to Brussels with the ivory or the money it returned. And it is all the more remarkable that Conrad chose objects like dominoes and piano-keys, not only because they were so trivial in a sitting-room or among a group of gentlemen trying to while away the time, but also because they are objects associated with leisure and culture, and telling us therefore that European culture is haunted by colonialism and its crimes, that it thrived on them while concealing its material (and highly unpalatable) aspects under a very civilized veil of refinement. Dominoes and piano keys make it possible for Conrad to go further than the denunciation of what takes place in Africa; they point at the other side of imperial domination. They associate Europeans who never took a direct part in colonization (but made use of the objects which were available thanks to it) to the process, revealing how the system of exploitation could go on since it safeguarded people's clear conscience ${ }^{12}$ and concealed the material realities of colonialism behind the veil of culture. However, it also contaminated humans: not only Kurtz, out there, whose head had become an "ivory ball" (48) - a sign of his subjection to ivory fetishism -, but also the Intended who plays the piano, or Marlow's friends who are allegedly interested only in navigation.

\section{3. "... as in some picture of a massacre or a pestilence"}

But objects do not only point at the circulation of goods between Africa and Europe and at the ethical and moral questions raised by colonialism, they also force us to pay attention to Conrad's aesthetic strategies when dealing with what Marlow calls the "unspeakable". In the "grove of death" passage, Marlow, just arrived at the first station, discovers the dying men. What he sees is so shocking that he can show it to us only at a remove, by transforming it, domesticating it. As Allan Simmons puts it, "Marlow's narrative enacts the dilemma of representing 'atrocity' generally: what is the language to communicate that of which we can't speak? Is there a 'rhetoric of the unsayable'? [...] the scale of the 'horror' to which it alludes cannot be adequately conveyed through facts [...]" (Simmons 188-189). I would contend that if it cannot be "adequately conveyed through facts", it is made sensible through details, through apparently insignificant objects. In order to speak of "that of which we can't speak" and to protect himself from the trauma of the nightmarish encounter ${ }^{13}$ Marlow's solution is first to de-realise the scene in order to make it more acceptable for his listeners (and probably for Conrad's readers as well): he therefore concentrates on the description of the men's bodies, or rather on parts of their bodies seen separately, as if they were lifeless objects (bones, orbs of the eyes, fingers), like a painter who would try to make what stands before his eyes as precisely visible as possible - except that what he describes is anything but normal: 
Black rags were wound round their loins, and the short ends behind wagged to and fro like tails. I could see every rib, the joints of their limbs were like knots in a rope; [...]. (Conrad 2006, 15)

Near the same tree two more bundles of acute angles sat with their legs drawn up.

(17)

Such close-ups on body parts convey the dehumanization of these living corpses as well as Marlow's shock: it seems that he can register the situation only progressively, one image after another. He needs familiar images to come to terms with such horrific visions: as a consequence, the sailor mentions ropes and their knots when he looks at their joints, or resorts to literary similes ("it seemed to me I had stepped into a gloomy circle of some Inferno"; Conrad 2006, 16). Above all, he presents the scene to his listeners as a painting or a print, describing the dying bodies with terms borrowed from the visual arts, as if he were technically commenting on a work of art: "Black shapes crouched, lay, sat between the trees, leaning against the trunks, clinging to the earth, half coming out, half effaced within the dim light, in all the attitudes of pain, abandonment, and despair" (17, emphasis mine). At the end of the passage, Marlow explicitly associates what he sees with painting: "and all about others were scattered in every pose of contorted collapse, as in some picture of a massacre or a pestilence" (17). Conrad's readers may have thought of Romantic pictures by Delacroix or Gros for instance. Here, Marlow does two things: speaking of "knots in a rope", he de-realizes what is unbearable; and then he characterizes it as a "picture", i.e. aestheticizes what he saw, ${ }^{14}$ domesticating it in order to make it acceptable, first to himself, and then to his listeners... and of course ultimately to the readers: the "horror" of the scene is finally contained by the pictorial reference; the material reality of tortured bodies is veiled by the aesthetic approach and yet, at the same time it becomes conspicuous thanks to this aestheticisation.

There is, however, a second step in the process, as incongruous material details are again crucial in the description, and become elements that force us to take a side step, so to speak, and consider the "picture" from a different perspective:

The black bones reclined at full length with one shoulder against the tree, and slowly the eyelids rose and the sunken eyes looked up at me, enormous and vacant, a kind of blind, white flicker in the depths of the orbs, which died out slowly. The man seemed young - almost a boy - but you know with them it's hard to tell. I found nothing else to do but to offer him one of my good Swede's ship's biscuits I had in my pocket. The fingers closed slowly on it and held - there was no other movement and no other glance. He had tied a bit of white worsted round his neckWhy? Where did he get it? Was it a badge - an ornament - a charm - a propitiatory act? Was there any idea at all connected with it? It looked startling round his black neck, this bit of white thread from beyond the seas. (Conrad 2006, 17)

In this scene of horror, Marlow introduces a small piece of cloth which takes a particular importance in his description and about whose presence he can only offer hypotheses. I would like to make several remarks concerning the piece of cloth, whose surprising presence forbids us from yielding to the lulling effect of the Romantic "picture of a massacre or a pestilence": "[A] white thread from beyond the seas", it becomes a link, confirming that the scene of horror that takes place in Africa finds its origin in Europe. And the contrast between the white worsted and the man's black skin can also be re-inserted into the general pattern which constantly subverts the usual "cultural and moral hierarchy" (see Parry 44) in Marlow's story: in this case, the white and black bear no meaning of any sort, they are simply contrasting hues. For that 
matter, the piece of cloth works more or less in the same way as the dominoes or pianokeys, underlining the fact that there is no solution of continuity between the two continents and between what takes place in both.

Then, it also works for Marlow like what Roland Barthes calls the "punctum" (as opposed to the "studium"). Barthes defines the punctum as the "detail" that attracts the viewer's attention because it breaks the "unity" of the picture and "interrupts [his/ her] reading" (Barthes 41):

The second element will break (or punctuate) the studium. This time, it is not I who seek it out (as I invest the field of the studium with my sovereign consciousness), it is this element which rises from the scene, shoots out of it like an arrow, and pierces me. [...] This second element which will disturb the studium I shall therefore call punctum; for punctum is also: sting, speck, cut, little hole - and also a cast of the dice. A photograph's punctum is that accident which pricks me (but also bruises me, is poignant to me). (Barthes, 26; emphasis in the original text)

Marlow is obviously deeply shocked by what he sees in the grove of death. The piece of white worsted therefore gives him something he can rest his eyes on in this moment of extreme tension. But it also, and above all, works as the detail that "is poignant to [him]" and therefore "interrupts [his] reading", redirecting his gaze and forcing him to acknowledge the man's humanity: what the presence of the white worsted tells Marlow is that at one point in his life, the young man was an individual with a will of his own, who chose to put the piece of cloth around his neck. What the successive questions underline is that such a decision remains mysterious for Marlow, who cannot account for it but only make hypotheses, so that the detail transforms the meaning of the whole picture: the piece of cloth punctures the "picture," ${ }^{15}$ destroys its unity, forces Marlow (and the reader with him) to keep in mind that it is peopled by real human beings (not brushstrokes), and that the bones belong to living - or rather dying - bodies. The white worsted may be interpreted in many ways: as an image of the whites' power over him, as a noose around his neck prefiguring his imminent death, etc. But Marlow sees it as an expression of the man's choice, an ultimate manifestation of freedom in the midst of the dehumanizing process he is a victim of, a sign that he is still a human being. It brings back reality and its real atrocities into the picture. Focusing on the white worsted re-introduces a personal dimension, sympathy - and therefore the possibility of an ethical point of view. Adam Smith showed that sympathy is related to imagination and that emotions therefore have a moral value, as they encourage us to identify with others and empathize with them. ${ }^{16}$ This is exactly what happens here with Marlow: the white worsted "pricks" and "bruises" (Barthes 26) Marlow, forcing him to acknowledge the young man's sufferings. As a consequence, sympathy reintroduces the possibility of an ethical point of view in a scene that is otherwise largely aestheticized.

There may not be many objects in Heart of Darkness and they may at first glance look like details. A closer look reveals however that they are essential, not only because they create circuits of meaning throughout the novella, which point at the hidden aspects of colonialism but also because Conrad's "rhetoric of the unsayable" (Simmons 189) rests largely on these apparently unimportant objects - details through which the horror's daily manifestations are made visible, details that re-introduce the human element into the picture. Thus, looking at objects, we perceive that Conrad's aesthetic strategy in Heart of Darkness is based on the disruptive presence of these apparently insignificant objects: focusing on unexpected details suddenly transforms the picture he has carefully drawn, in the manner of an anamorphosis, and forces the readers to realize 
that the ethical and moral questions his novella raises are questions that concern them directly.

\section{BIBLIOGRAPHY}

Arasse, Daniel, Le Détail. Pour une histoire rapprochée de la peinture (1992), Paris : Champs/

Flammarion, 1996.

Barthes, Roland, Camera Lucida. Reflections on Photography, trans. Richard Howard, New York: Hill \& Wang, 1981.

Brown, Bill, A Sense of Things: The Object Matter of American Literature, Chicago: Chicago UP, 2003.

Conrad, Joseph, “An Outpost of Progress" in Tales of Unrest (1898), Harmondsworth: Penguin, 1983.

Conrad, Joseph, The Nigger of the 'Narcissus' (1897), ed. Jacques Berthoud, Oxford: The World's Classics, 1984.

Conrad, Joseph, The Collected Letters of Joseph Conrad, vol. 2 (1898-1902), eds. Frederick Karl \& Laurence Davies, Cambridge: Cambridge UP, 1986.

Conrad, Joseph Heart of Darkness (1899), ed. Paul B. Armstrong, New York: Norton, 2006.

Freedgood, Elaine, The Ideas in Things. Fugitive Meaning in the Victorian Novel, Chicago: U of Chicago P, 2006.

Hochschild, Adam, King Leopold's Ghost, Boston, New York: Houghton Mifflin Company, 1999.

Jameson, Fredric, The Political Unconscious. Narrative as a Socially Symbolic Act (1981), London: Routledge, 2002.

Karl, Frederick \& Laurence Davies (eds.), The Collected Letters of Joseph Conrad, vol. 2 (1898-1902), Cambridge: Cambridge UP, 1986.

Marx, Karl, Capital (1867), London: Penguin Classics, 1990.

Murphy, Ryan Francis, "Exterminating the Elephant in Heart of Darkness", The Conradian 38.2 (2013): 1-17.

Parry, Benita, "The Moment and Afterlife of Heart of Darkness", in Conrad in the $21^{\text {st }}$ Century. Contemporary Approaches and Perspectives, eds. Carola M. Kaplan, Peter Lancelot Mallios \& Andrea White, London: Routledge, 2005.

Peters, John G., Conrad and Impressionism, Cambridge: Cambridge UP, 2001.

Simmons, Allan, "Conrad, Casement and the Congo Atrocities", in Joseph Conrad's Heart of Darkness (1899), ed. Paul B. Armstrong, New York: Norton, 2006.

Smith, Adam, The Theory of Moral Sentiment (1759), Harmondsworth: Penguin Classics, 2010. Watt, Ian, "Impressionism and Symbolism in Heart of Darkness", Southern Review 13.1 (1977): 96-113. 


\section{NOTES}

1. "In the secret dictionary of novel criticism [...] objects are weak metonyms for the subjects they adorn or generic markers of the real they indicate" (Freedgood 9-12; 36).

2. The question of the ivory and white worsted in the novella has already been studied by Ryan Francis Murphy, while the role of details has been tackled, among others, by Ian Watt or John G. Peters.

3. Letter to R.B. Cunningham Graham, Feb. 8, 1899.

4. Such disconnection between object and use also suggests a world in which causality has become problematic or been utterly defeated.

5. “[...] le détail se manifestait alors comme un écart ou une résistance par rapport à l'ensemble du tableau; il semblait avoir pour fonction de transmettre une information parcellaire, différente du message global de l'œuvre - ou indifférente à celle-ci." (Translation mine)

6. "Mais le détail peut aussi se manifester comme le lieu où s'est condensé l'investissement du tableau (et de son thème) par son auteur ; son écart fait alors affleurer les enjeux du peintre, au travail dans son œuvre" (Arasse 14 ; translation mine).

7. Freedgood concentrates on Victorian literature. In Jane Eyre for instance, she shows that "mahogany becomes more than a weak metonym for wealth and taste; it figures, first of all, itself. It tells a story of imperial domination - the history of deforestation and slavery from Madeira to Jamaica - that crosshatches the manifest narrative of Jane Eyre [...]" (Freedgood 3).

8. In "An Outpost of Progress", Carlier also characterizes them as "rubbish" and "rags" (Conrad 1983, 89).

9. The name of Kurtz occurs 122 times; the pilgrims are mentioned 31 times as well. Clearly, if we trust the recurrence of terms, human interest seems to outweigh material interest.

10. See also 24 and 35: "colonial products like tea and sugar made consumers anxious because they threatened to bring home the violence that attended their production. This anxiety suggests the ways in which acts of consumption were regarded as moral choices."

11. Not to mention the fact that the dominoes were also called bones, a term which is highly evocative in Heart of Darkness.

12. Neither Marlow nor the frame narrator, who mention the piano-keys and dominoes, associate them with what made their presence possible. Readers must make their own deductions.

13. Confronted with the dying boy, he admits that "[he] found nothing else to do but to offer him one of [his] good Swede's ship's biscuits [...]" (Conrad 2006, 17).

14. It is what F. Jameson reproaches Conrad with: concealing economic (or imperialist) realities behind an aesthetic veil. Yet there are moments when Conrad (or in the present case, Marlow) points to the presence of the veil for us, making it possible to see what lies behind and underlining its function: the screen thus becomes a revealer (see Jameson 194-270; 202).

15. It can be noticed that this way of zooming in on "details" is a characteristic feature with Marlow. He is helped in that process by optical instruments like the binoculars which reveal to him that the "round knobs" around Kurtz's compound are in fact dried heads. Such "unveiling" "pricks" Marlow in the same manner as the white worsted: "And then I made a brusque movement, and one of the remaining posts of that vanished fence leaped up in the field of my glass. You remember I told you I had been struck at the distance by certain attempts at ornamentation, rather remarkable in the ruinous aspect of the place. Now I had suddenly a nearer view, and its first result was to make me throw my head back as if before a blow. Then I went carefully from post to post with my glass, and I saw my mistake. These round knobs were not ornamental but symbolic; they were expressive and puzzling, striking and disturbing - food for thought and also for the vultures if there had been any looking down from the sky" (Conrad 2006, 57). 
16. "Though our brother is on the rack, as long as we ourselves are at our ease, our senses will never inform us of what he suffers. They never did, and never can, carry us beyond our own person, and it is by the imagination only that we can form any conception of what are his sensations. [...] It is the impressions of our own senses only, not those of his, which our imaginations copy. By the imagination we place ourselves in his situation, we conceive ourselves enduring the same torments, we enter as it were into his body, and become in some measure the same person with him, and thence form some idea of his sensations, and even feel something which, though weaker in degree, is not altogether unlike them" (Smith 2).

\section{ABSTRACTS}

There are only a limited number of objects in Heart of Darkness and they may at first glance look like details. A closer look reveals however that they are essential, not only because they create circuits of meaning throughout the novella which point at hidden aspects of colonialism but also because Conrad's aesthetic strategy rests largely on these apparently unimportant objects details through which the horror's daily manifestations are made visible, details that may reintroduce the human element into the picture. This article analyses how a limited number of objects shed a revealing light onto the novella's meaning. Two instances of particular importance (ivory and the white worsted round the dying black man's throat in the "grove of death" scene) are analyzed in detail in order to show that what could not be conveyed through facts when the novella was first published is made sensible thanks to the disruptive presence of apparently insignificant objects. Drawing on postcolonial theory, art criticism and R. Barthes's "punctum", the paper underlines how focusing on details forces the readers to realize that the ethical and moral questions raised by the novella are questions that concern them directly.

Les objets sont peu nombreux dans Cour des ténèbres. Une lecture attentive montre pourtant qu'ils ne sont pas de simples détails mais les supports essentiels d'une circulation du sens qui met en lumière certains aspects cachés du colonialisme : ils sont essentiels à la stratégie esthétique de Conrad, dirigeant le regard du lecteur vers les manifestations de l'« horreur » qu'ils rendent visible, introduisant aussi de l'affect dans le discours de Marlow. Cet article analyse la manière dont un nombre limité d'objets jette une lumière révélatrice sur ce que raconte Marlow. Deux exemples (l'ivoire et les différents objets qui en sont composés, et le brin de laine autour du cou du jeune noir agonisant dans la scène du «bosquet de la mort») sont abordés en détail de manière à montrer que ce que le roman ne dénonce pas directement est rendu sensible à travers la présence d'objets apparemment de peu d'importance dans la narration. S'appuyant sur la théorie postcoloniale, la place du détail en peinture et le concept de "punctum » emprunté à Roland Barthes, l'article étudie comment la présence de ces « détails » dirige le regard du lecteur vers les questions éthiques et morales soulevées par Cœur des ténèbres.

\section{INDEX}

oeuvrecitee Heart of Darkness (J. Conrad)

Mots-clés: objet, détail, ivoire, esthétique, circulation du sens, Conrad (Joseph)

Keywords: object, detail, ivory, aesthetics, circuits of meaning, Conrad (Joseph) 


\section{AUTHOR}

\section{NATHALIE MARTINIÈRE}

Nathalie Martinière is Professor at the University of Limoges where she teaches literature. She works on Conrad's fiction and on postcolonial rewritings of classics. She is the author of Figures du double: du personage au texte (2008), she co-edited Rewriting in the $20^{\text {th }}$ et $21^{\text {st }}$ centuries: Aesthetic Choice or Political Act? (2015) and recently contributed the part on Heart of Darkness in a volume entitled Expériences de l'histoire, poétiques de la mémoire (2017). She is the editor of L'Époque Conradienne. 